\title{
Anatomically induced changes in rice leaf mesophyll conductance explain the variation in photosynthetic nitrogen use efficiency under contrasting nitrogen supply
}

Limin Gao, Zhifeng Lu, Lei Ding, Kailiu Xie, Min Wang, Ning Ling and Shiwei Guo*

\begin{abstract}
Background: The ratio of $\mathrm{CO}_{2}$ mesophyll conductance $\left(g_{\mathrm{m}}\right)$ to Ribulose-1, 5-bisphosphate carboxylase/oxygenase (Rubisco) content has been suggested to positively affect photosynthetic nitrogen use efficiency (PNUE). The anatomical basis of $g_{m}$ has been quantified, but information on the relationship between cell-level anatomies and PNUE is less advanced. Here, hydroponic experiments were conducted in rice plants supplied with ammonium $\left(\mathrm{NH}_{4}{ }^{+}\right)$and nitrate $\left(\mathrm{NO}_{3}{ }^{-}\right)$under three $\mathrm{N}$ levels (low, $0.71 \mathrm{mM}$; intermediate, $2.86 \mathrm{mM}$; high, $7.14 \mathrm{mM}$ ) to investigate the gas exchange parameters, leaf anatomical structure and PNUE.

Results: The results showed a lower PNUE in plants supplied with high nitrogen and $\mathrm{NH}_{4}{ }^{+}$, which was positively correlated with the $g_{m} /$ Rubisco ratio. A one-dimensional within-leaf model revealed that the resistance to $\mathrm{CO}_{2}$ diffusion in the liquid phase $\left(r_{\text {liq }}\right)$ dominated the overall mesophyll resistance $\left(r_{\mathrm{m}}\right)$, in which $\mathrm{CO}_{2}$ transfer resistance in the cell wall, cytoplasm and stroma were significantly affected by nitrogen supply. The chloroplast surface area exposed to intercellular space $\left(S_{c}\right)$ per Rubisco rather than the $g_{m} / S_{c}$ ratio was positively correlated with PNUE and was thus considered a key component influencing PNUE.
\end{abstract}

Conclusion: In conclusion, our study emphasized that $S_{c}$ was the most important anatomical trait in coordinating $g_{\mathrm{m}}$ and PNUE with contrasting $\mathrm{N}$ supply.

Keywords: Leaf anatomies, $\mathrm{NH}_{4}{ }^{+}, \mathrm{NO}_{3}{ }^{-}$, Mesophyll conductance, PNUE, Rubisco

\footnotetext{
* Correspondence: sguo@njau.edu.cn

Jiangsu Provincial Key Lab for Organic Solid Waste Utilization, National

Engineering Research Center for Organic-based Fertilizers, Jiangsu

Collaborative Innovation Center for Solid Organic Waste Resource Utilization,

Nanjing Agricultural University, Weigang 1, Nanjing 210095, China
}

(c) The Author(s). 2020 Open Access This article is licensed under a Creative Commons Attribution 4.0 International License, which permits use, sharing, adaptation, distribution and reproduction in any medium or format, as long as you give appropriate credit to the original author(s) and the source, provide a link to the Creative Commons licence, and indicate if changes were made. The images or other third party material in this article are included in the article's Creative Commons licence, unless indicated otherwise in a credit line to the material. If material is not included in the article's Creative Commons licence and your intended use is not permitted by statutory regulation or exceeds the permitted use, you will need to obtain permission directly from the copyright holder. To view a copy of this licence, visit http://creativecommons.org/licenses/by/4.0/ The Creative Commons Public Domain Dedication waiver (http://creativecommons.org/publicdomain/zero/1.0/) applies to the data made available in this article, unless otherwise stated in a credit line to the data. 


\section{Background}

Photosynthetic nitrogen use efficiency (PNUE), determined as the ratio of photosynthesis rate $\left(P_{\mathrm{n}}\right)$ to leaf organic nitrogen content [1], is a key component of nitrogen use efficiency (NUE) and an indicator of the relationship between leaf nitrogen $(\mathrm{N})$ and $P_{\mathrm{n}}$. Under the present atmosphere, the unsaturated $\mathrm{CO}_{2}$ concentration in $\mathrm{C} 3$ leaves influences the carboxylation of Ribulose-1,5-disphosphate (RuBP) and results in a finite $P_{\mathrm{n}}$, which fails to match the increase in leaf $\mathrm{N}$ and induces a decrease in PNUE [2]. By using an "evolutionary" algorithm, the partitioning of photosynthetic enzymes was altered based on a fixed total amount of protein-nitrogen for maximizing $P_{\mathrm{n}}$, and the result showed that an increase in Ribulose-1, 5-bisphosphate carboxylase/ oxygenase (Rubisco) was required to maximize $P_{\mathrm{n}}$ [3]. It was also well documented that higher leaf $\mathrm{N}$ allocation into Rubisco was linked with an enhancement in PNUE [4].

Numerous studies have clarified that the enhancement in Rubisco activity is another favorable candidate for improving RuBP carboxylation efficiency and $P_{\mathrm{n}}$ because of its poor catalytic ability under ambient conditions due to the low $\mathrm{CO}_{2}$ concentration and the low affinity for $\mathrm{CO}_{2}$ $[1,5]$. As the substrate of Rubisco, $\mathrm{CO}_{2}$ concentration in the chloroplast $\left(C_{\mathrm{c}}\right)$, which is determined by stomatal conductance $\left(g_{\mathrm{s}}\right)$ and mesophyll conductance $\left(g_{\mathrm{m}}\right)$, plays a dominant role in regulating Rubisco activity [6,7]. It has been demonstrated that $g_{\mathrm{m}}$ induces $40 \%$ of the total decrease in $\mathrm{CO}_{2}$ concentration between the atmosphere and the carboxylation sites of Rubisco [8]. In a previous study, Li et al. [5] argued that an increase in $g_{\mathrm{m}}$ was not sufficient to meet the carboxylation demand of the increased Rubisco content and eventually resulted in a decreased PNUE. Therefore, it is speculated that factors affecting $g_{\mathrm{m}}$ would influence Rubisco activity and the relationship between $P_{\mathrm{n}}$ and leaf $\mathrm{N}$ content.

Evidence is now mounting that $g_{\mathrm{m}}$ is largely dependent on leaf anatomical characteristics, including leaf thickness, cell wall thickness and chloroplast morphology [9, 10]. Higher leaf density and thicker mesophyll cell walls contribute to a reduction in $g_{\mathrm{m}}[9,11-14]$, and mesophyll and/or chloroplast surface areas exposed to the intercellular space, $S_{\text {mes }}$ and $S_{\mathrm{c}}$, respectively, are positively correlated with $g_{\mathrm{m}}$ [15]. The overall importance of different anatomical traits in the restriction of $g_{\mathrm{m}}$ varies [16]. For gymnosperms, the strongest sources of $g_{\mathrm{m}}$ are cell wall and chloroplast thickness, variation in chloroplast shape and size, and $S_{\mathrm{c}}$ [9]. In lycophytes and bryophytes, the highest $\mathrm{CO}_{2}$ diffusive resistance is mainly driven by extremely high cell wall thickness and low $S_{\mathrm{c}}$ [17]. Even though the anatomical factors influencing $g_{\mathrm{m}}$ have been widely studied, the role of these anatomical factors in influencing PNUE and their relative contribution in rice plants are still largely unknown.

Leaf anatomy is remarkably influenced by $\mathrm{N}$ nutrition; for example, decreasing leaf thickness and smaller chloroplasts with no starch granules have been detected in nitrogendeficient leaves, while high-N leaves have more large chloroplasts with well-developed grana, stroma lamellae and starch granules per mesophyll cell [5, 18-20]. For different nitrogen forms, increased leaf thickness and a doubling of chloroplast volume with a larger internal membrane length have been found in $\mathrm{NH}_{4}{ }^{+}$-fed plants compared with $\mathrm{NO}_{3}{ }^{-}$-fed plants [21-23]. In this study, we examine the responses of leaf anatomical characteristics, including leaf thickness, mesophyll cell size, chloroplast length and thickness, chloroplast number per mesophyll cell under $\mathrm{NH}_{4}{ }^{+}$and $\mathrm{NO}_{3}{ }^{-}$ nutrition with different $\mathrm{N}$ levels; moreover, we discuss the implications for understanding leaf trait variation with changes in N nutrition along the PNUE. Our objectives of the present study were as follows: (1) to identify the response of PNUE and leaf anatomical traits upon $\mathrm{NH}_{4}{ }^{+}$and $\mathrm{NO}_{3}{ }^{-}$nutrition at different $\mathrm{N}$ levels; (2) to clarify the role of leaf anatomical factors in coordinating the $g_{\mathrm{m}}$ and PNUE under $\mathrm{NH}_{4}{ }^{+}$and $\mathrm{NO}_{3}{ }^{-}$nutrition supply; and (3) to investigate the most limiting fraction of leaf anatomy in determining PNUE under different $\mathrm{N}$ supply.

\section{Results}

Effects of nitrogen supply on rice photosynthetic nitrogen use efficiency (PNUE)

Compared with those with low nitrogen supply (LAN and LNN), rice biomass and leaf area with intermediate and high nitrogen supply increased by $70-73 \%$ and $33-$ $42 \%$ under $\mathrm{NH}_{4}{ }^{+}$nutrition and by $30-48 \%$ and $40-41 \%$ under $\mathrm{NO}_{3}{ }^{-}$nutrition, respectively (Table 1 ). There were no significant differences in rice biomass and leaf area between the intermediate and high nitrogen supply conditions. Rice biomass was less affected by nitrogen forms at the same nitrogen level, while for intermediate nitrogen supply, the leaf area was decreased by $10 \%$ in $\mathrm{NO}_{3}{ }^{-}$fed plants than in $\mathrm{NH}_{4}{ }^{+}$-fed plants (Table 1). The leaf $\mathrm{N}$ content $\left(N_{\mathrm{L}}\right)$ was $54-62 \%$ and $66-80 \%$ higher under intermediate $\mathrm{N}$ supply and high $\mathrm{N}$ supply than under low $\mathrm{N}$ supply and was decreased by $9-11 \%$ under $\mathrm{NO}_{3}{ }^{-}$ nutrition compared with that under $\mathrm{NH}_{4}{ }^{+}$nutrition (Table 1). The Rubisco content was 26, 21 and $21 \%$ lower under low $\mathrm{NO}_{3}{ }^{-}$(LNN), intermediate $\mathrm{NO}_{3}{ }^{-}$ (MNN) and high $\mathrm{NO}_{3}{ }^{-}$(HNN) than that under low $\mathrm{NH}_{4}{ }^{+}$(LAN), intermediate $\mathrm{NH}_{4}{ }^{+}$(MAN) and high $\mathrm{NH}_{4}{ }^{+}$ (HAN), respectively (Table 1$)$. The stomatal conductance $\left(g_{\mathrm{s}}\right)$ was less affected by $\mathrm{N}$ supply than mesophyll conductance $\left(g_{\mathrm{m}}\right)$, which was increased by 72 and $24 \%$ in HAN and HNN, respectively, compared with that in LAN and LNN and decreased by $4-30 \%$ under $\mathrm{NO}_{3}{ }^{-}$ compared to $\mathrm{NH}_{4}{ }^{+}$nutrition (Table 1). Neither nitrogen supply levels nor nitrogen forms affected the chloroplast $\mathrm{CO}_{2}$ concentration $\left(C_{\mathrm{c}}\right)$. With increasing leaf $\mathrm{N}$ content, the light-saturated photosynthetic rate $\left(P_{\mathrm{n}}\right)$ increased, while the photosynthetic nitrogen use efficiency (PNUE) 
Table 1 Effects of different nitrogen supply levels on rice biomass $(\mathrm{g})$, leaf area $\left(\mathrm{cm}^{2}\right)$, leaf nitrogen content $\left(\mathrm{N}_{\mathrm{L}}, \mathrm{g} \mathrm{m} \mathrm{m}^{-2}\right)$, Rubisco content $\left(\mathrm{g} \mathrm{m}^{-2}\right)$, stomatal conductance $\left(g_{\mathrm{s}}, \mathrm{mol} \mathrm{CO} \mathrm{CO}^{-2} \mathrm{~s}^{-1}\right)$, mesophyll conductance $\left(g_{\mathrm{m}}\right.$, mol $\left.\mathrm{CO}_{2} \mathrm{~m}^{-2} \mathrm{~s}^{-1}\right)$, chloroplast $\mathrm{CO}_{2}$ concentration $\left(C_{c}, \mu \mathrm{mol} \mathrm{mol}{ }^{-1}\right)$, photosynthesis rate $\left(P_{\mathrm{n}}, \mu \mathrm{mol} \mathrm{m} \mathrm{m}^{-2} \mathrm{~s}^{-1}\right)$, and photosynthetic nitrogen use efficiency (PNUE, $\mu \mathrm{mol}$ $\mathrm{CO}_{2} \mathrm{mmol}^{-1} \mathrm{~N} \mathrm{~S}^{-1}$ ). Rice plants ("Zhendao 11") were supplied with $\mathrm{NH}_{4}^{+}$(AN) or $\mathrm{NO}_{3}^{-}(\mathrm{NN})$ under 3 different amounts, low $\mathrm{N}(0.71$ $\mathrm{mM}, \mathrm{LAN}$ and LNN), intermediate $\mathrm{N}(2.86 \mathrm{mM}, \mathrm{MAN}$ and MNN), and high N (7.14 mM, HAN and HNN). Data are presented as the means \pm SD of four replications. Significant differences $(P<0.05)$ between treatments are indicated by different letters

\begin{tabular}{llllllllll}
\hline Treatments & Biomass & Area & $\boldsymbol{N}_{\mathbf{L}}$ & Rubisco & $\boldsymbol{g}_{\mathbf{s}}$ & $\boldsymbol{g}_{\mathbf{m}}$ & $\boldsymbol{C}_{\mathbf{c}}$ & $\boldsymbol{P}_{\mathbf{n}}$ & PNUE \\
\hline LAN & $3.29 \mathrm{~b}$ & $658 \mathrm{c}$ & $1.55 \mathrm{~d}$ & $2.02 \mathrm{~d}$ & $0.35 \mathrm{~b}$ & $0.16 \mathrm{c}$ & $180 \mathrm{ab}$ & $24.61 \mathrm{~b}$ & $0.22 \mathrm{~b}$ \\
MAN & $5.71 \mathrm{a}$ & $932 \mathrm{a}$ & $2.38 \mathrm{~b}$ & $3.16 \mathrm{~b}$ & $0.45 \mathrm{a}$ & $0.24 \mathrm{ab}$ & $171 \mathrm{ab}$ & $28.74 \mathrm{a}$ & $0.17 \mathrm{~cd}$ \\
HAN & $5.59 \mathrm{a}$ & $873 \mathrm{ab}$ & $2.58 \mathrm{a}$ & $3.67 \mathrm{a}$ & $0.49 \mathrm{a}$ & $0.28 \mathrm{a}$ & $187 \mathrm{a}$ & $29.25 \mathrm{a}$ & $0.16 \mathrm{~d}$ \\
LNN & $3.77 \mathrm{~b}$ & $595 \mathrm{c}$ & $1.30 \mathrm{e}$ & $1.49 \mathrm{e}$ & $0.27 \mathrm{~b}$ & $0.16 \mathrm{c}$ & $165 \mathrm{~b}$ & $25.00 \mathrm{~b}$ & $0.27 \mathrm{a}$ \\
MNN & $4.92 \mathrm{a}$ & $837 \mathrm{~b}$ & $2.11 \mathrm{c}$ & $2.50 \mathrm{c}$ & $0.44 \mathrm{a}$ & $0.20 \mathrm{bc}$ & $176 \mathrm{ab}$ & $29.86 \mathrm{a}$ & $0.20 \mathrm{bc}$ \\
HNN & $5.57 \mathrm{a}$ & $834 \mathrm{~b}$ & $2.34 \mathrm{~b}$ & $2.90 \mathrm{~b}$ & $0.44 \mathrm{a}$ & $0.19 \mathrm{bc}$ & $176 \mathrm{ab}$ & $30.30 \mathrm{a}$ & $0.18 \mathrm{~cd}$ \\
\hline
\end{tabular}

decreased (Table 1, Fig. 1a, b). The PNUE was 21, 17 and $14 \%$ higher in LNN, MNN and HNN than in LAN, MAN and HAN, respectively (Table 1 ). Positive correlations existed between PNUE and both the $C_{\mathrm{c}} /$ Rubisco ratio and the $g_{\mathrm{m}} /$ Rubisco ratio (Fig. 1c, d).

\section{Effects of nitrogen supply on leaf anatomical properties}

With increasing leaf $\mathrm{N}$ supply levels, leaf thickness $\left(T_{\mathrm{L}}\right)$ and mesophyll cell thickness $\left(T_{\mathrm{m}}\right)$ increased in $\mathrm{NH}_{4}{ }^{+}$-fed plants but decreased in $\mathrm{NO}_{3}{ }^{-}$-fed plants (Supplementary Fig. S1, Fig. 2a, b). Leaf dry mass per area $\left(M_{\mathrm{A}}\right)$, leaf density $\left(D_{\mathrm{L}}\right)$ and mesophyll cell wall thickness $\left(T_{\mathrm{mc}}\right)$ were increased by high $\mathrm{N}$ supply either with $\mathrm{NH}_{4}{ }^{+}$or $\mathrm{NO}_{3}{ }^{-}$, and were lower under $\mathrm{NO}_{3}{ }^{-}$nutrition than under $\mathrm{NH}_{4}{ }^{+}$nutrition. Mesophyll surface area exposed to intercellular airspace $\left(S_{\text {mes }}\right)$ and the chloroplast surface area facing intercellular airspace $\left(S_{\mathrm{c}}\right)$ were upregulated significantly by increasing the nitrogen supply level (Fig. 2b). The $S_{\text {mes }}$ increased by $22-37$ and $21 \%$ under intermediate and high $\mathrm{N}$ supply conditions in $\mathrm{NH}_{4}{ }^{+}$and $\mathrm{NO}_{3}{ }^{-} \mathrm{nu}-$ trition, respectively, and the corresponding $S_{\mathrm{c}}$ increased by $22-38 \%$ and $21-24 \%$, both compared with their respective low $\mathrm{N}$ supply conditions. No obvious differences in $S_{\mathrm{c}}$ between $\mathrm{NH}_{4}{ }^{+}$and $\mathrm{NO}_{3}{ }^{-}$under low $\mathrm{N}$ levels were observed, but the $S_{\mathrm{c}}$ decreased by 11 and $20 \%$ under MNN and HNN, respectively, compared to that under MAN and HAN (Fig. 2b).

We further analyzed the chloroplast number per mesophyll cell $\left(N_{\mathrm{c}}\right)$, chloroplast length $\left(L_{\mathrm{c}}\right)$, chloroplast thickness $\left(T_{\mathrm{c}}\right)$, chloroplast surface area $\left(\operatorname{Sur}_{\mathrm{c}}\right)$, chloroplast volume $\left(\mathrm{Vol}_{\mathrm{c}}\right)$ and chloroplast section area $\left(\mathrm{Sec}_{\mathrm{c}}\right)$. $L_{\mathrm{c}}$ was lower in $\mathrm{NO}_{3}{ }^{-}$-fed plants than in $\mathrm{NH}_{4}{ }^{+}$-fed plants under intermediate and high $\mathrm{N}$ levels (Supplementary Fig. S1, Fig. 2c). Compared with that in LAN and LNN, the $T_{\mathrm{c}}$ was increased by $13-27 \%$ in MAN and HAN and 23-29\% in MNN and HNN (Supplementary Fig. S1, Fig. 2c). Higher $\mathrm{Sur}_{\mathrm{c}}$ and $\mathrm{Vol}_{\mathrm{c}}$ were observed under high $\mathrm{N}$ supply. The chloroplast size was decreased under $\mathrm{NO}_{3}{ }^{-}$ nutrition by $10-22 \%, 15-33 \%$, and $10-40 \%$ in $\mathrm{Sur}_{\mathrm{c}}, \mathrm{Vol}_{\mathrm{c}}$ and $\mathrm{Sec}_{\mathrm{c}}$ under low $\mathrm{N}$, intermediate $\mathrm{N}$ and high $\mathrm{N}$ supply, respectively (Supplementary Fig. S1, Fig. 2d).

\section{Anatomical limitations of mesophyll conductance}

The values of $g_{\mathrm{m}}$ calculated according to the methods of Harley et al. [24] and Tomas et al. [16] were strongly positively linearly correlated (Supplementary Fig. S2, $R^{2}=$ 0.936). Further quantitative analysis showed that both the resistance in the gas phase $\left(r_{\text {ias }}\right)$ and proportion of gasphase limitations $\left(l_{\text {ias }}\right)$ of $g_{\mathrm{m}}$ had little impact on the overall mesophyll resistance (Fig. 3), and that the liquid phase resistance $\left(r_{\text {liq }}\right)$ was responsible for the limited $g_{\mathrm{m}}$ majority, among which stroma played a dominant role. High $\mathrm{N}$ supply significantly increased the resistance in the cell wall $\left(r_{\mathrm{cw}}\right)$ and stroma $\left(r_{\mathrm{st}}\right)$; compared with low $\mathrm{N}$ supply, $g_{\mathrm{m}}$ limited by the stroma $\left(l_{\mathrm{st}}\right)$ was increased by $9-10 \%$ under moderate $\mathrm{N}$ supply and by $9-13 \%$ under high $\mathrm{N}$ supply (Fig. 3b). Consistent with the absolute cytoplasm resistance, $g_{\mathrm{m}}$ limited by the cytoplasm $\left(l_{\mathrm{cyt}}\right)$ and cell wall $\left(l_{\mathrm{cw}}\right)$ were downregulated under high $\mathrm{N}$ supply and $\mathrm{NO}_{3}{ }^{-}$nutrition, respectively (Fig. 3). Among all the components, $r_{\mathrm{cw}}$ was the primary component affected by $\mathrm{N}$ forms and was 19, 23 and 16\% higher under $\mathrm{NH}_{4}{ }^{+}$nutrition than under $\mathrm{NO}_{3}{ }^{-}$nutrition in low $\mathrm{N}$, intermediate $\mathrm{N}$ and high $\mathrm{N}$ supply, respectively (Fig. 3a).

\section{Discussion}

Effects of $\mathrm{N}$ supply on the $g_{\mathrm{m}}$ /Rubisco ratio and photosynthetic nitrogen use efficiency (PNUE)

Decreased PNUE under high $\mathrm{N}$ supply has been reported in previous and present studies (Table 1, Fig. 1) [5, 25-27]; referring to $\mathrm{N}$ forms, higher PNUE under $\mathrm{NO}_{3}{ }^{-}$nutrition than $\mathrm{NH}_{4}{ }^{+}$nutrition in the present study is consistent with results in barley (Hordeum vulgare L.) [28], pine [29], and cucumber [30]. Leaf nitrogen allocation is an important factor influencing PNUE. Onoda et al. [31] indicated that a higher fraction of photosynthetic nitrogen in electron transport and Rubisco would contribute to increased PNUE in leaves with lower dry mass per area $\left(M_{\mathrm{A}}\right)$, while in leaves 

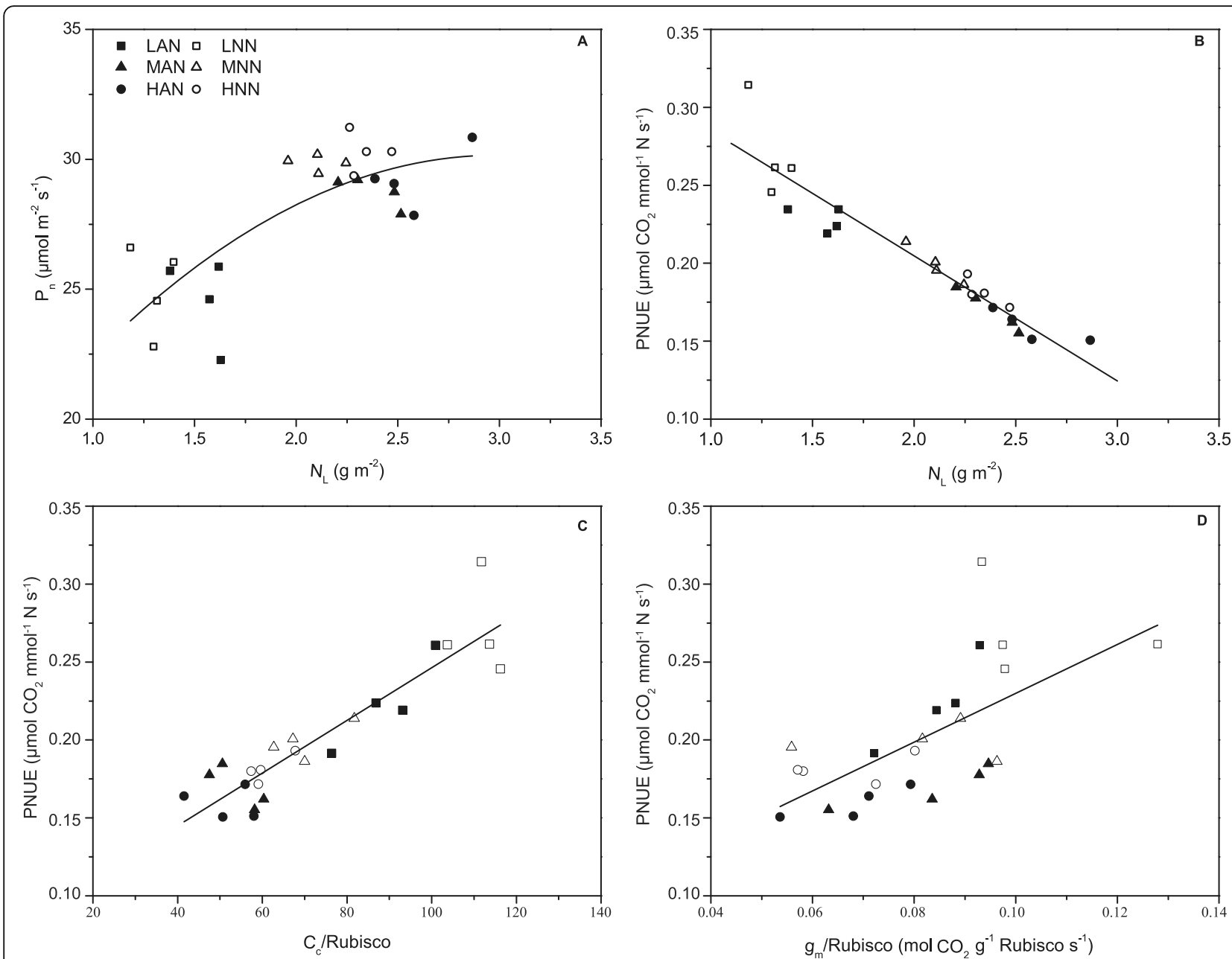

Fig. 1 The relationship between leaf $N$ content $\left(N_{L}\right)$ and the photosynthetic rate $\left(P_{n}\right)(\mathbf{a})$ and photosynthetic nitrogen use efficiency (PNUE) (b) and the relationship between PNUE and the ratio of chloroplast $\mathrm{CO}_{2}$ concentration to Rubisco ( $C_{c} /$ Rubisco) (c) and the ratio of mesophyll conductance to Rubisco $\left(g_{\mathrm{m}} /\right.$ Rubisco) (d). Each point represents one replicate (four replicates per treatment). The lines represent the following regression equations: $\mathbf{a} y=-1.8756 x^{2}+11.3310 x+13.0290, R^{2}=0.6228, P<0.05 ; \mathbf{b} y=-0.0763 x+0.3565, R^{2}=0.7886, P<0.05 ; \mathbf{c} y=0.0017 x+$ $0.0774, R^{2}=0.8295, P<0.01 ; \mathbf{d} \mathrm{y}=1.5663 \mathrm{x}+0.0733, R^{2}=0.4215, P<0.01$

with higher $M_{\mathrm{A}}$, the over-investment of nitrogen in photosynthetic nitrogen and/or cell walls would reduce PNUE [1]. The effect of the proportion of Rubisco in leaf $\mathrm{N}$ content on PNUE can be expressed based on Eq. (6):

$$
\text { PNUE }=\frac{g_{\mathrm{m}}}{\text { Rubisco }}\left(C_{\mathrm{i}}-C_{\mathrm{c}}\right) \frac{\text { Rubisco }}{N_{\mathrm{L}}}
$$

Our study detected that the Rubisco allocation ratio was increased under high nitrogen supply but decreased under $\mathrm{NO}_{3}{ }^{-}$nutrition compared with $\mathrm{NH}_{4}{ }^{+}$nutrition; however, the portion of Rubisco in leaf $\mathrm{N}$ content was not associated with PNUE (Fig. 4a). These results implied that Rubisco activity, rather than its content, played a dominant role in regulating PNUE $[1,5,32]$.
An increased Rubisco allocation ratio requires increased $\mathrm{CO}_{2}$ partial pressure at the carboxylation site $\left(C_{\mathrm{c}}\right)$ to meet carboxylation demands; however, the extent of the increase in $C_{\mathrm{c}}$ was less than that in Rubisco content, which resulted from the finite stomatal conductance $\left(g_{\mathrm{s}}\right)$ and mesophyll conductance $\left(g_{\mathrm{m}}\right)$. Li et al. [5] demonstrated that the smaller increases in $g_{\mathrm{m}}$ relative to Rubisco content resulted in relatively lower $\mathrm{CO}_{2}$ levels in chloroplasts and PNUE (Fig. 1c, d), which implied that the $g_{\mathrm{m}} /$ Rubisco ratio rather than the absolute value of $g_{\mathrm{m}}$ was the key factor that regulates PNUE. We further compared the gap between estimated $g_{\mathrm{m}}$ and $C_{\mathrm{c}}$ proposed by Harley et al. [24] (Eq. 5, 6) and theoretical $C_{\mathrm{c}}\left(C_{\mathrm{c} \text {-Theoretical }}\right)$ and $g_{\mathrm{m}}$ ( $\left.g_{\mathrm{m} \text {-Theoretical }}\right)$, which were calculated as follows based on Ding et al. [27], to evaluate the equilibrium state of $g_{\mathrm{m}}$ and Rubisco under different $\mathrm{N}$ nutrition conditions: 

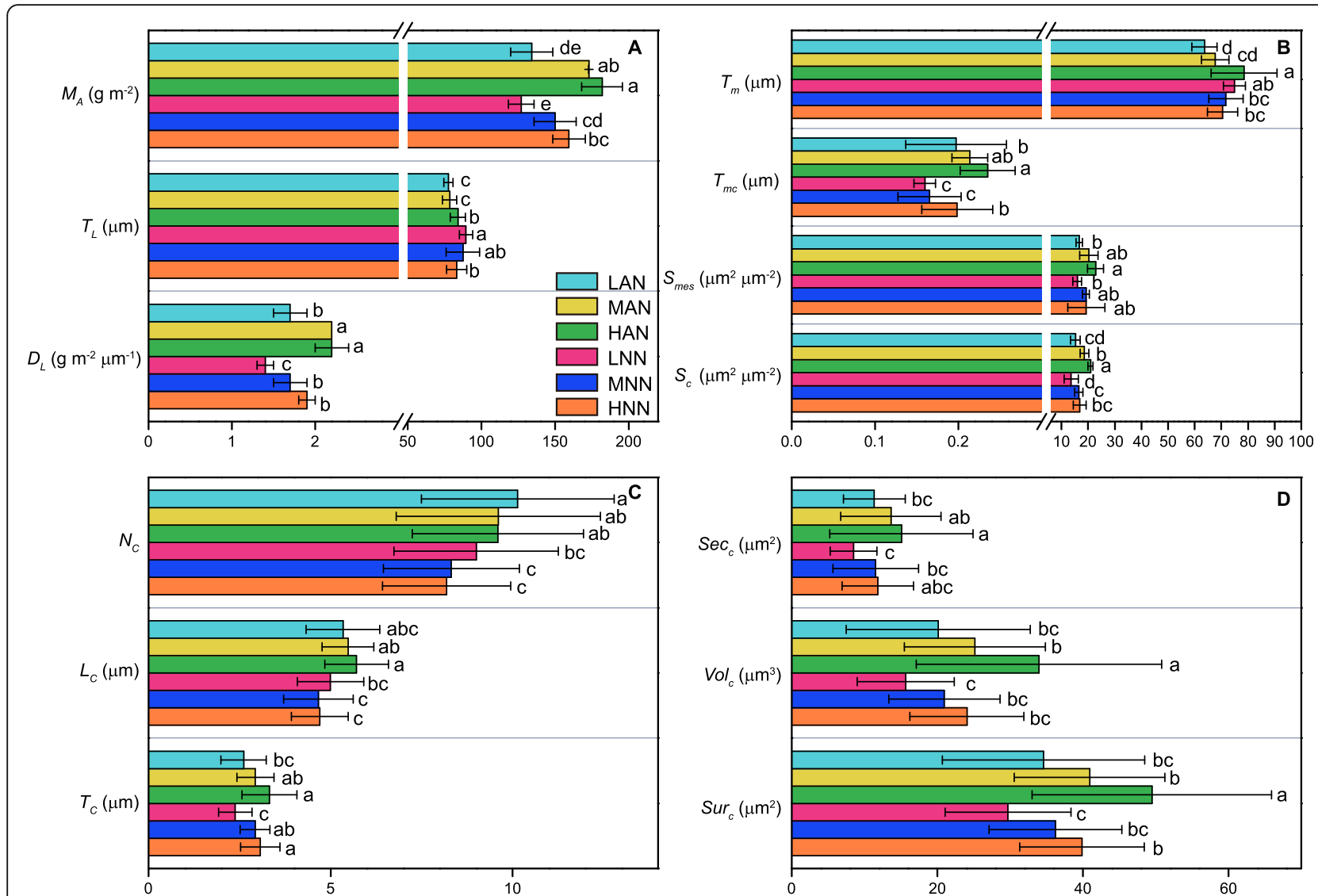

Fig. 2 Effects of different nitrogen supply levels on integral leaf variables (a), mesophyll cell $(\mathbf{b})$ and chloroplast (c, $\mathbf{d})$ anatomical characteristics. $M_{\mathrm{A}}\left(\mathrm{g} \mathrm{m}^{-2}\right)$, leaf dry mass per area. $T_{\mathrm{L}}(\mu \mathrm{m})$, leaf thickness. $D_{\mathrm{L}}\left(\mathrm{g} \mathrm{m}^{-2} \mu \mathrm{m}^{-1}\right)$, leaf density. $T_{\mathrm{m}}(\mu \mathrm{m})$, mesophyll thickness. $T_{\mathrm{mc}}(\mu \mathrm{m})$, mesophyll cell wall thickness. $S_{\text {mes }}\left(\mu \mathrm{m}^{2} \mu \mathrm{m}^{-2}\right)$, mesophyll surface area exposed to intercellular airspace. $S_{c}\left(\mu \mathrm{m}^{2} \mu \mathrm{m}^{-2}\right)$, chloroplast surface area exposed to intercellular airspace. $N_{c}$ chloroplast number per mesophyll cell. $L_{c}(\mu \mathrm{m})$, chloroplast length. $T_{c}(\mu \mathrm{m})$, chloroplast thickness. $\operatorname{Sec}_{c}\left(\mu \mathrm{m}^{2}\right)$, chloroplast section area. Vol ${ }_{c}\left(\mu \mathrm{m}^{3}\right)$, chloroplast volume. Sur $\left(\mu \mathrm{m}^{2}\right)$, chloroplast surface area. The error bars indicate the standard deviation and at least 15 replicates were conducted for each parameter

$g_{\mathrm{m}}$ - Theoretical (intermediate or high $\mathrm{N}$ )

$=$ Rubisco (intermediate or high $\mathrm{N}$ )

$$
\times \frac{g_{\mathrm{m}}}{\text { Rubisco }}(\text { low N) }
$$

$$
\begin{aligned}
& \left.C_{c}-\text { Theoretical (intermediate or high } \mathrm{N}\right) \\
& =\text { Rubisco }(\text { intermediate or high } \mathrm{N}) \\
& \quad \times \frac{C_{\mathrm{c}}}{\text { Rubisco }}(\text { low } \mathrm{N})
\end{aligned}
$$

As shown in Fig. 5, both theoretical and estimated $C_{\mathrm{c}}$ and/or $g_{\mathrm{m}}$, as well as the differences between them, increased obviously with increasing leaf $\mathrm{N}$ content, and the gap between theoretical and estimated $C_{\mathrm{c}}$ and/or $g_{\mathrm{m}}$ under $\mathrm{NH}_{4}{ }^{+}$nutrition was larger than that under $\mathrm{NO}_{3}{ }^{-}$ nutrition. These results confirmed that the balance between Rubisco content and $C_{\mathrm{c}}$ and/or $g_{\mathrm{m}}$ was weaker when high $\mathrm{N}$ and $\mathrm{NH}_{4}{ }^{+}$were supplied, and the relatively lower $C_{\mathrm{c}}$ failed to meet the carboxylation demands of the increased Rubisco content, resulting in decreased PNUE (Fig. 1c, d).

\section{Overall importance of leaf anatomy in determining $g_{\mathrm{m}}$ and PNUE}

When leaf nitrogen content was expressed on a leaf dry mass basis, no significant differences in leaf $\mathrm{N}$ content between $\mathrm{NH}_{4}{ }^{+}$and $\mathrm{NO}_{3}{ }^{-}$nutrition were obtained. Therefore, the discrepancies in PNUE between different $\mathrm{N}$ forms were primarily caused by the difference in $M_{\mathrm{A}}$ (Fig. 2), which resulted from leaf anatomy characteristics such as leaf density $\left(D_{\mathrm{L}}\right)$, leaf thickness $\left(T_{\mathrm{L}}\right)$ and cell wall thickness $\left(T_{\mathrm{mc}}\right)$. In $\mathrm{NO}_{3}{ }^{-}$-fed plants, the lower $M_{\mathrm{A}}$ was the ultimate result of lower $D_{\mathrm{L}}$ and $T_{\mathrm{mc}}$. However, a lower $M_{\mathrm{A}}$ was not always related to a lower $g_{\mathrm{m}}$, as observed in the present study; Hassiotou et al. [8] found a negative relationship between $M_{\mathrm{A}}$ and $g_{\mathrm{m}}$ in the range of $100-500 \mathrm{~g} \mathrm{~m}^{-2}$ of $M_{\mathrm{A}}$, while Hanba et al. [33] clarified a positive relationship in the same range of $M_{\mathrm{A}}$. These contrasting results were explained by different ways to 

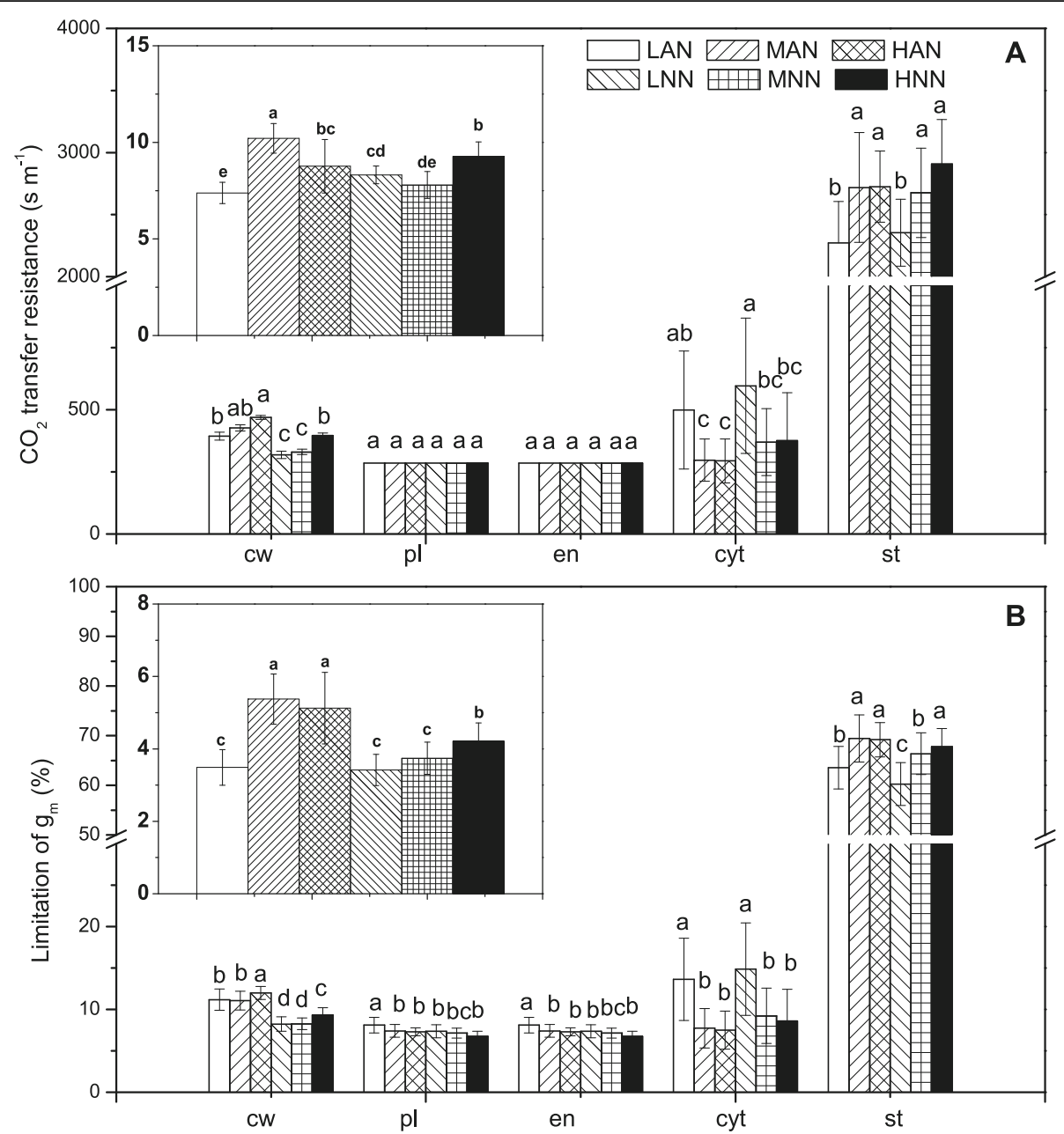

Fig. 3 Anatomical limitations of mesophyll conductance $\left(g_{m}\right)(\mathbf{a})$ and the share of the overall $g_{m}$ limitation (b) by cell wall (cw), plasma membrane (pl), chloroplast envelope (en), cytoplasm (cyt) and stroma (st) in rice leaves supplied with $\mathrm{NH}_{4}^{+}(\mathrm{AN})$ or $\mathrm{NO}_{3}{ }^{-}$(NN) under 3 different amounts, low N (0.71 $\mathrm{mM}, \mathrm{LAN}$ and LNN), intermediate $N(2.86 \mathrm{mM}, \mathrm{MAN}$ and $\mathrm{MNN})$, and high $\mathrm{N}(7.14 \mathrm{mM}, \mathrm{HAN}$ and HNN). The inset figure shows the anatomical limitations of $g_{\mathrm{m}}$ and the share of the overall $g_{\mathrm{m}}$ limitation by gas phase. The error bars indicate the standard deviation and at least 15 replicates were conducted for each parameter. Different letters indicate statistically significant differences $(P<0.05)$ between different treatments

enhance $M_{\mathrm{A}}$, as the increases in $D_{\mathrm{L}}$ and $T_{\mathrm{L}}$ were associated with higher $g_{\mathrm{m}}$, while the opposite conclusion would be obtained if the increase in $M_{\mathrm{A}}$ was a result of a thickened cell wall [8]. Our positive correlation between $M_{\mathrm{A}}$ and $g_{\mathrm{m}}$ implied that the contributions of $D_{\mathrm{L}}$ and/or $T_{\mathrm{L}}$ compensated for the inhibitory effect of $T_{\mathrm{mc}}$ on $g_{\mathrm{m}}$.

To qualify the relative importance of each leaf anatomy trait in explaining $g_{\mathrm{m}}$, a one-dimensional within-leaf model was calculated to clarify the limitation of $g_{\mathrm{m}}$ in each process [16]. The results showed that more than $90 \%$ of the total limitation of $g_{\mathrm{m}}$ came from $L_{\text {liq }}$, which was a consequence of limitation in the cell wall $\left(L_{\mathrm{cw}}\right)$, plasma membrane $\left(L_{\mathrm{pl}}\right)$, envelope $\left(L_{\text {en }}\right)$, cytoplasm $\left(L_{\text {cyt }}\right)$, and stroma $\left(L_{\mathrm{st}}\right)$ (Fig. 3) [34]. The decreased contribution of cytoplasmic resistance to $g_{\mathrm{m}}$ under high $\mathrm{N}$ resulted from the decreased distance between adjacent chloroplasts, rather than the distance between the cell wall and chloroplasts [16], and the increase in chloroplast thickness $\left(T_{\mathrm{c}}\right)$ extended the transport path for $\mathrm{CO}_{2}$ from the chloroplast membrane to the carboxylation site in the interior of chloroplasts and resulted in an increasing in $r_{\mathrm{st}}[35,36]$. Except for the resistance of each part, the chloroplast surface area exposed to intercellular airspace $\left(S_{\mathrm{c}}\right)$ was a paramount factor affecting $\mathrm{CO}_{2}$ liquid resistance $\left(r_{\text {liq }}\right)$. However, the decreased $r_{\text {cyt }}$ and increased $S_{\mathrm{c}}$ partially compensated for the increased $r_{\mathrm{st}}$ under high $\mathrm{N}$ supply and resulted in an increased $g_{\mathrm{m}}$, although the effects were weak and did not match the increase in Rubisco content.

Considering the dominant role of $S_{\mathrm{c}}$ in determining $g_{\mathrm{m}}$, the $g_{\mathrm{m}} /$ Rubisco in Eq. (1) was replaced by the product of $g_{\mathrm{m}} / S_{\mathrm{c}}$ and $S_{\mathrm{c}} /$ Rubisco to demonstrate the effect of leaf anatomies and $g_{\mathrm{m}}$ on PNUE, which can be expressed as follows: 

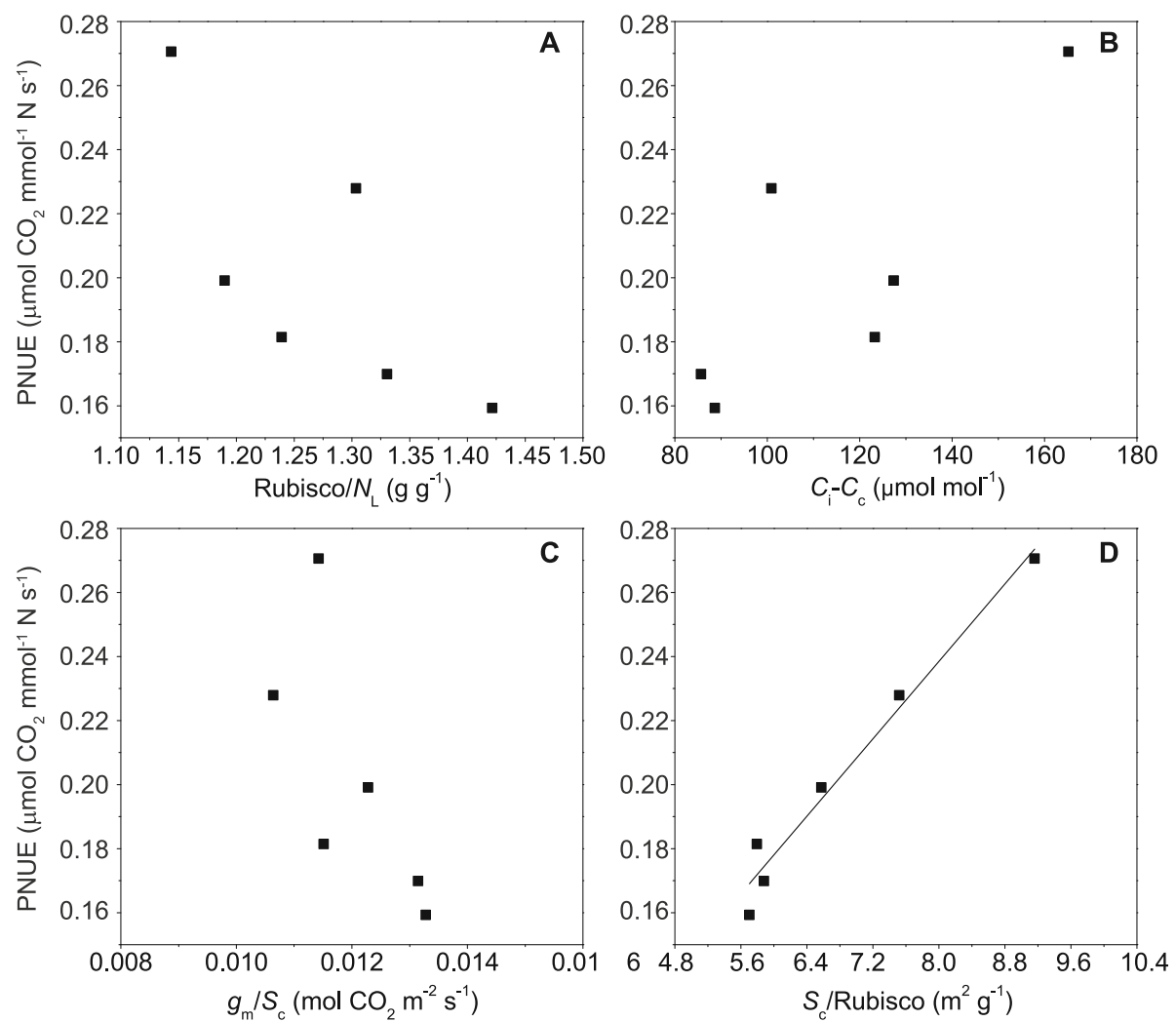

Fig. 4 The relationship between photosynthetic nitrogen use efficiency (PNUE) and the ratio of Rubisco to leaf $\mathrm{N}$ content (Rubisco/ $\left./ N_{L}\right)(\mathbf{a})$, the difference between intercellular $\mathrm{CO}_{2}$ concentration and chloroplast $\mathrm{CO}_{2}$ concentration $\left(\mathrm{C}_{\mathrm{i}}-\mathrm{C}_{\mathrm{c}}\right)(\mathbf{b})$, the ratio of mesophyll conductance to chloroplast surface area exposed to intercellular airspace $\left(g_{m} / S_{c}\right)(\mathbf{c})$, and the ratio of chloroplast surface area exposed to intercellular airspace to Rubisco ( $S_{C} /$ Rubisco) (d). Data represent the mean of 4 replicates for PNUE, Rubisco, $N_{L}, C_{i}, C_{c}, g_{m}$ and at least 15 replicates for $S_{c}$. The line in the figure represents the following regression equation: $y=0.0299 x-0.0019, R^{2}=0.9700, P<0.01$

$$
\text { PNUE }=\frac{g_{\mathrm{m}}}{S_{\mathrm{c}}} \frac{S_{\mathrm{c}}}{\text { Rubisco }} \frac{\text { Rubisco }}{N_{\mathrm{L}}}\left(C_{\mathrm{i}}-C_{\mathrm{c}}\right)
$$

According to the formula above and Terashima et al. [37], a positive correlation would be summarized between PNUE and $g_{\mathrm{m}} / S_{\mathrm{c}}$, which emphasized the potential role of leaf anatomical characteristics except for $S_{\mathrm{c}}$, as well as the activity of carbonic anhydrase (CA) in contributing to PNUE [37]. However, the weak negative relationship between $g_{\mathrm{m}} / S_{\mathrm{c}}$ and PNUE and the significant positive correlation between the $S_{\mathrm{c}} /$ Rubisco ratio and PNUE suggested the dominant role of $S_{\mathrm{c}}$ in influencing PNUE. Due to the limited knowledge of the relationship between PNUE and the $S_{\mathrm{c}} /$ Rubisco ratio, Onoda et al. [14] did not take this component into consideration when they analyzed the physiological and structural tradeoffs underlying the leaf economics spectrum, and they argued that $S_{\mathrm{c}}$ per Rubisco may not correlate strongly with $M_{\mathrm{A}}$ or PNUE. However, we detected that $S_{\mathrm{c}}$ per Rubisco was a critical parameter associated with PNUE in rice plants supplied with different $\mathrm{N}$ nutrition levels. Similar results were well documented in a review by Terashima et al. [15] and Terashima et al. [37], in which they speculated that, from the perspective of Rubisco and nitrogen use efficiency, thicker leaves with larger $S_{\mathrm{c}}$ were advantageous because the increased ratio of $S_{\mathrm{c}}$ to Rubisco would increase chloroplast $\mathrm{CO}_{2}$ concentration. The increased $S_{\mathrm{c}} /$ Rubisco ratio in $\mathrm{NO}_{3}{ }^{-}-$and high $\mathrm{N}$-fed plants partially resulted from the lower leaf density, which allowed more chloroplast surface area to be exposed to intercellular airspace (Fig. 2a).

\section{Conclusions}

In conclusion, we demonstrated that PNUE is decreased in rice plants supplied with high $\mathrm{N}$ and ammonium nutrition, which results from unbalanced increases in $g_{\mathrm{m}}$ and Rubisco content. Nitrogen-induced variation in $g_{\mathrm{m}}$ is associated with leaf anatomical traits, especially chloroplast surface area exposed to intercellular airspace $\left(S_{\mathrm{c}}\right)$. We further concluded that the $S_{\mathrm{c}} /$ Rubisco ratio is directly related to the response of PNUE to $\mathrm{N}$ supply and that its increase is advantageous to the increase in PNUE. 


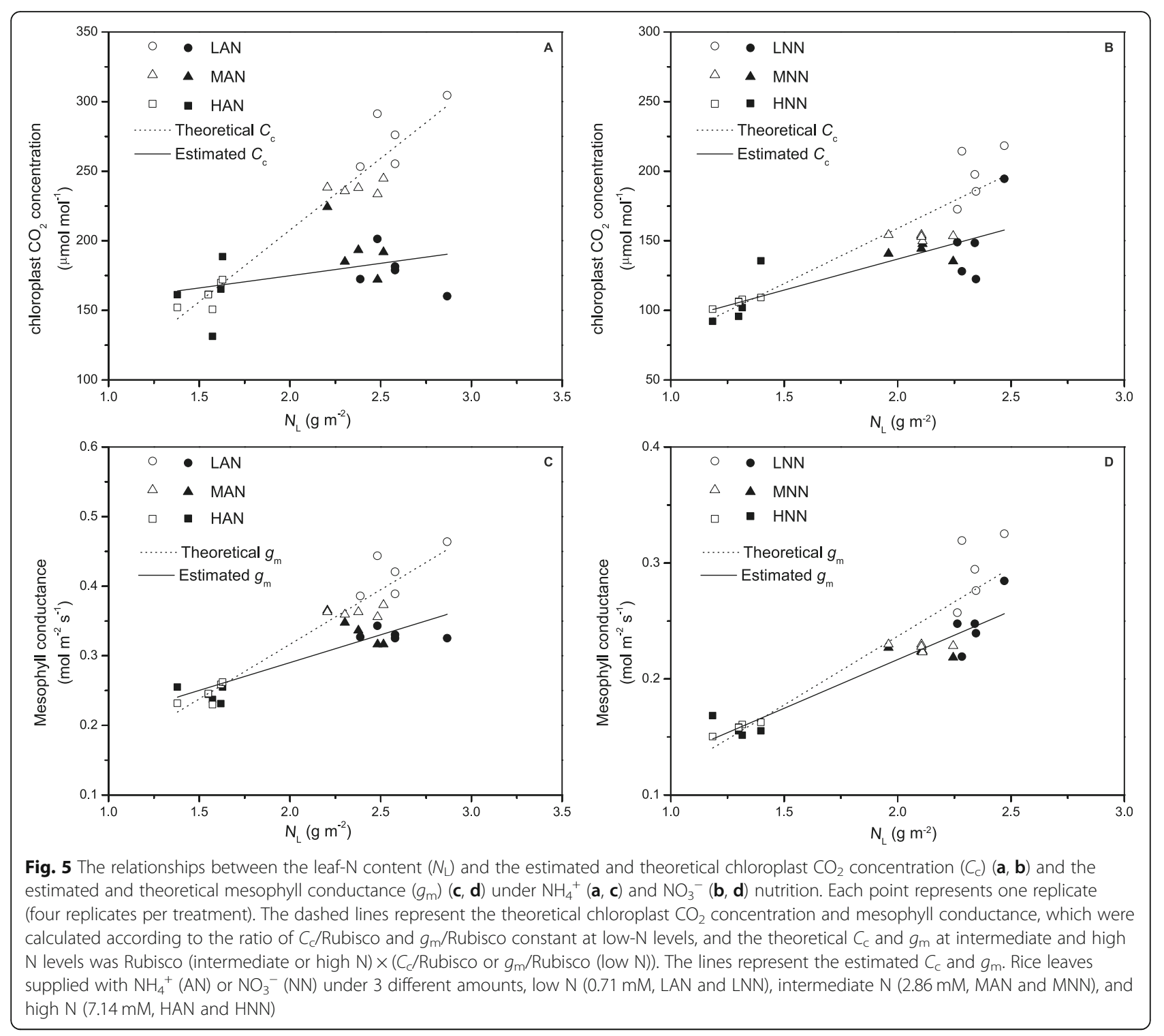

\section{Methods}

\section{Plant material and growth conditions}

Rice seeds (Oryza sativa L., ssp. japonica inbred, cv. 'Zhendao 11') were purchased from Mingtian Seed Company (Nanjing, China), disinfected with $10 \% \mathrm{H}_{2} \mathrm{O}_{2}$ for $30 \mathrm{~min}$ and germinated in $2.0 \mathrm{mM} \mathrm{CaSO}_{4}$ at $25^{\circ} \mathrm{C}$. The rice seedlings were transferred to $6 \mathrm{~L}$ rectangular containers $(30 \times 20 \times 10 \mathrm{~cm})$ when the seedlings developed 2.5 visible leaves, and one quarter-strength mixture of $\mathrm{NH}_{4}{ }^{+}$and $\mathrm{NO}_{3}{ }^{-}$nutrient solution (for composition, see below) was supplied. Three days later, the seedlings were transferred to a one half-strength nutrient solution. After 6 days, the seedlings were supplied with full-strength nutrient solution for 1 week, after which the seedlings were supplied with either $\left(\mathrm{NH}_{4}\right)_{2} \mathrm{SO}_{4}(\mathrm{AN})$ or $\mathrm{Ca}\left(\mathrm{NO}_{3}\right)_{2}(\mathrm{NN})$ at three different $\mathrm{N}$ levels: low $\mathrm{N}(0.71 \mathrm{mM})$, intermediate $\mathrm{N}$ (2.86
$\mathrm{mM})$, and high $\mathrm{N}(7.14 \mathrm{mM})$. Thus, six treatments were applied: LAN (low $\mathrm{NH}_{4}{ }^{+}$), MAN (intermediate $\mathrm{NH}_{4}{ }^{+}$), HAN (high $\mathrm{NH}_{4}^{+}$), $\mathrm{LNN}\left(\right.$ low $\mathrm{NO}_{3}{ }^{-}$), $\mathrm{MNN}$ (intermediate $\mathrm{NO}_{3}{ }^{-}$), and $\mathrm{HNN}$ (high $\mathrm{NO}_{3}{ }^{-}$). In addition, the macronutrients in the solution were as follows (mM): $0.32 \mathrm{P}^{2} \mathrm{KH}_{2} \mathrm{PO}_{4}, 1.02$ $\mathrm{K}$ as $\mathrm{K}_{2} \mathrm{SO}_{4}$ and $\mathrm{KH}_{2} \mathrm{PO}_{4}$ and $1.65 \mathrm{Mg}$ as $\mathrm{MgSO}_{4}$. The micronutrients were $(\mu \mathrm{M})$ as follows: $35.8 \mathrm{Fe}$ as Fe-EDTA, $9.10 \mathrm{Mn}$ as $\mathrm{MnCl}_{2} \cdot 4 \mathrm{H}_{2} \mathrm{O}, 0.52 \mathrm{Mo}$ as $\left(\mathrm{NH}_{4}\right)_{6} \mathrm{Mo}_{7} \mathrm{O}_{24} \cdot 4 \mathrm{H}_{2} \mathrm{O}$, $18.5 \mathrm{~B}$ as $\mathrm{H}_{3} \mathrm{BO}_{3}, 0.15 \mathrm{Zn}$ as $\mathrm{ZnSO} 4.7 \mathrm{H}_{2} \mathrm{O}, 0.16 \mathrm{Cu}$ as $\mathrm{CuSO}_{4} \cdot 5 \mathrm{H}_{2} \mathrm{O}$ and $100 \mathrm{Si}$ as $\mathrm{Na}_{2} \mathrm{SiO}_{3} \cdot 9 \mathrm{H}_{2} \mathrm{O} . \mathrm{CaCl}_{2}$ was added to the AN, LNN, and MNN solutions to adjust the Ca level to that of the HNN treatment. The nitrification inhibitor dicyandiamide (DCD) was added to each nutrient solution to prevent the oxidation of $\mathrm{NH}_{4}{ }^{+}$. The nutrient solutions were changed every 3 days, and the $\mathrm{pH}$ was adjusted to $5.50 \pm 0.05$ each day with $0.1 \mathrm{M} \mathrm{HCl}$ or $\mathrm{NaOH}$. All the 
treatments were replicated 5 times with a completely randomized design. The temperature in the greenhouse was maintained at $30^{\circ} \mathrm{C}$ during the day and $18^{\circ} \mathrm{C}$ at night. Light was supplied by SON-TAGRO $400 \mathrm{~W}$ bulbs, and the distance between the light and the rice plants was approximately $60 \mathrm{~cm}$. The light intensity was maintained at a minimum of $1000 \mu \mathrm{mol}$ photons $\mathrm{m}^{-2} \mathrm{~s}^{-1}$ at the leaf level using a 14-h photoperiod.

\section{Measurement of biomass and leaf $\mathrm{N}$ content}

After all the measurements were completed, plant dry weight was determined after oven-drying at $105^{\circ} \mathrm{C}$ for $30 \mathrm{~min}$ and then at $70^{\circ} \mathrm{C}$ to a constant weight. Pictures of the leaves used for the measurement of $P_{\mathrm{n}}$ were taken with a camera along with a benchmark to calibrate, and the leaf area was obtained by Image J Pro Plus, after which the leaves were dried and digested with $\mathrm{H}_{2} \mathrm{SO}_{4}$ $\mathrm{H}_{2} \mathrm{O}_{2}$ at $260-270{ }^{\circ} \mathrm{C}$. The leaf $\mathrm{N}$ concentration was determined using a digital colorimeter (AutoAnalyzer 3; Bran+Luebbe).

\section{Gas exchange measurements}

Twenty days after treatments, a Li-Cor 6400 infrared gas analyzer was used for the simultaneous measurement of light-saturated photosynthesis $\left(P_{\mathrm{n}}\right)$ and chlorophyll fluorescence on the newly expanded leaves from 9: 00 to $15: 00$. Leaf temperatures were $25^{\circ} \mathrm{C}$, the relative humidity was $45 \%$, and photosynthetic photon flux density (PPFD) was $1500 \mu \mathrm{mol} \mathrm{m} \mathrm{m}^{-2} \mathrm{~s}^{-1}$ for all measurements. After equilibration to a steady state, $P_{\mathrm{n}}$ was recorded and the photosynthetic nitrogen use efficiency (PNUE) was calculated as the ratio of $P_{\mathrm{n}}$ to the leaf nitrogen content per leaf area. The fluorescence $\left(F_{\mathrm{s}}\right)$ was also measured simultaneously, and a $0.8 \mathrm{~s}$ saturating pulse of light (approx. $8000 \mu \mathrm{mol} \mathrm{m} \mathrm{m}^{-2} \mathrm{~s}^{-1}$ ) was applied to measure the maximum fluorescence $\left(F_{\mathrm{m}}{ }^{\prime}\right)$. The efficiency of photosystem II $\left(\Phi_{\mathrm{PSII}}\right)$ was calculated as $\Phi_{\mathrm{PSII}}=1-F_{\mathrm{s}} / F_{\mathrm{m}}$ '. The total electron transport rate $\left(J_{\mathrm{T}}\right)$ was calculated as $J_{\mathrm{T}}=\Phi_{\mathrm{PSII}} \times \mathrm{PPFD} \times \alpha_{\text {leaf }} \times \beta$, where $\alpha_{\text {leaf }}$ and $\beta$ were leaf absorption and the proportion of quanta absorbed by photosystem II, respectively. In this study, $\alpha_{\text {leaf }}$ was also assumed to be 0.85 , and $\beta$ was assumed to be 0.5 [38].

The following equations proposed by Harley et al. [24] were used to calculate the $\mathrm{CO}_{2}$ mesophyll conductance $\left(g_{\mathrm{m}}\right)$ and chloroplast $\mathrm{CO}_{2}$ concentration $\left(C_{\mathrm{c}}\right)$ :

$$
\begin{aligned}
& g_{\mathrm{m}}=\frac{P_{\mathrm{n}}}{C_{\mathrm{i}}-\Gamma * \frac{J_{\mathrm{T}}+8 \times\left(P_{\mathrm{n}}+R_{\mathrm{d}}\right)}{J_{\mathrm{T}}-4 \times\left(P_{\mathrm{n}}+R_{\mathrm{d}}\right)}} \\
& C_{\mathrm{c}}=C_{\mathrm{i}}-\frac{P_{\mathrm{n}}}{g_{\mathrm{m}}}
\end{aligned}
$$

where $C_{\mathrm{i}}$ is the intercellular $\mathrm{CO}_{2}$ concentration, $\Gamma^{*}$ is the $\mathrm{CO}_{2}$ compensation point and $R_{\mathrm{d}}$ is the mitochondrial respiration rate in the light. In the present experiment, $\Gamma^{*}$ and $R_{\mathrm{d}}$ were measured on newly expanded leaves according to the method of $\mathrm{Li}$ et al. [39]. PPFDs in the cuvette were controlled as the series of 150, 300, and $600 \mu \mathrm{mol} \mathrm{m}^{-2} \mathrm{~s}^{-1}$. At each PPFD, the ambient $\mathrm{CO}_{2}$ concentration in the cuvette was adjusted as the series of 25, 50, 75 and $100 \mu \mathrm{mol} \mathrm{CO}_{2} \mathrm{~mol}^{-1}$. Thirty minutes prior to initiating measurements, leaves were placed in the cuvette with a PPFD of $600 \mu \mathrm{mol}$ photons $\mathrm{m}^{-2} \mathrm{~s}^{-1}$ and a $C_{\mathrm{a}}$ of $100 \mu \mathrm{mol} \mathrm{CO} \mathrm{mol}^{-1}$.

\section{Anatomical analysis}

For the anatomical analysis, approximately $1-2 \mathrm{~mm}^{2}$ leaf sections were cut and fixed in FAA (95\% ethanol: glacial acetic acid: formalin: distilled water $=10: 1: 2: 7)$, dehydrated in ethanol series, and embedded in paraffin. After cutting into $6 \mu \mathrm{m}$ transverse sections with a microtome and mounting on glass, the glass was stained with Safranin $\mathrm{O}$ and fast green and then mounted in DPX mounting medium. Images of each section were obtained with a light microscope (BX 53, Olympus) with a CCD camera (eXcope X3, DIX, Korea). Leaf thickness $\left(T_{\mathrm{L}}\right)$, mesophyll thickness $\left(T_{\mathrm{m}}\right)$, leaf density $\left(D_{\mathrm{L}}\right)$, and the volume fraction of intercellular air space $\left(f_{\text {ias }}\right)$ were measured and/or calculated from at least 5 sections from four different leaves, and at least 5 different fields of view were observed for a given section of images. $D_{\mathrm{L}}$ and $f_{\text {ias }}$ were calculated as:

$$
\begin{aligned}
& D_{\mathrm{L}}=\frac{M_{\mathrm{A}}}{T_{\mathrm{L}}} \\
& f_{\text {ias }}=1-\frac{\sum S_{\mathrm{m}}}{T_{\mathrm{m}} \mathrm{W}}
\end{aligned}
$$

where $M_{\mathrm{A}}$ is the specific leaf weight $\left(\mathrm{g} \mathrm{m}^{-2}\right), \Sigma S_{\mathrm{m}}$ is the total sectional area of mesophyll cells, and $\mathrm{W}$ is the width of the section.

For the transmission electron microscope (TEM) analysis, approximately $1-2 \mathrm{~mm}^{2}$ leaf sections were cut from the middle of newly expanded leaves using two razor blades, fixed in $2.5 \%$ glutaraldehyde $\left(0.1 \mathrm{~mol} \mathrm{~L}^{-1}\right.$ phosphate buffer, $\mathrm{pH} 7.0$ ) and postfixed with $2 \%$ osmium tetroxide. Specimens were dehydrated in a graded acetone series and embedded in Epon 812. Ultrathin crosssections of $90 \mathrm{~nm}$ for transmission electron microscopy (TEM) were cut with a Power Tome-XL ultramicrotome, stained with $2 \%$ uranyl acetate, and examined with an H-7650 transmission electron microscope. For each sample, 15 cross-sections were chosen to measure mesophyll cell wall thickness $\left(T_{\mathrm{mc}}\right)$ and total length of the mesophyll cells $\left(L_{\mathrm{mes}}\right)$ and chloroplasts $\left(L_{\mathrm{ch}}\right)$ facing the intercellular air space. At least 40 chloroplasts from TEM were observed to measure the chloroplast traits, including chloroplast length $\left(L_{\mathrm{c}}\right)$, chloroplast thickness $\left(T_{\mathrm{c}}\right)$, chloroplast section area $\left(\operatorname{Sec}_{\mathrm{c}}\right)$, distance between 
two neighbor chloroplasts $\left(\Delta L_{\mathrm{chl}}\right)$, and chloroplast distance from the cell wall $\left(\Delta L_{\mathrm{cyt}}\right)$. The surface area of mesophyll cells to the intercellular air-spaces $\left(S_{\text {mes }}\right)$, the surface area of chloroplasts exposed to intercellular airspace $\left(S_{\mathrm{c}}\right)$, the chloroplast surface area $\left(\mathrm{Sur}_{\mathrm{c}}\right)$ and volume $\left(\mathrm{Vol}_{\mathrm{c}}\right)$ were calculated by using the following formula:

$$
\begin{aligned}
& S_{\mathrm{mes}}=\frac{L_{\mathrm{mes}}}{\mathrm{W}} \mathrm{F} \\
& S_{\mathrm{c}}=\frac{L_{\mathrm{ch}}}{L_{\mathrm{mes}}} S_{\mathrm{mes}}
\end{aligned}
$$

where $\mathrm{W}$ is the width of the measured section, and $\mathrm{F}$ is the curvature correction factor and taken as 1.55 [40].

$$
\begin{aligned}
& \operatorname{Sur}_{\mathrm{c}}=4 \times \pi \times\left(\mathrm{a} \times \mathrm{b}^{2}\right)^{2 / 3} \\
& \operatorname{Vol}_{\mathrm{c}}=(4 / 3) \times \pi \times\left(\mathrm{a} \times \mathrm{b}^{2}\right)
\end{aligned}
$$

where $\mathrm{a}=L_{\mathrm{c}} / 2$, and $\mathrm{b}=T_{\mathrm{c}} / 2$.

The chloroplast number per mesophyll cell $\left(N_{\mathrm{c}}\right)$ was determined according to the method of Pyke [41]. Briefly, the leaves were cut into $1-5 \mathrm{~mm}$ widths with a scalpel or razor blade, submerged in $3.5 \%(\mathrm{v} / \mathrm{v})$ glutaraldehyde in a tube and kept in the dark at room temperature for $1 \mathrm{~h}$. The glutaraldehyde solution was then replaced with $0.1 \mathrm{M} \mathrm{Na-EDTA}$ $(\mathrm{pH} 9)$, and the leaf discs were heat-blocked at $60^{\circ} \mathrm{C}$ for $12 \mathrm{~h}$ and incubated overnight in the dark at $4{ }^{\circ} \mathrm{C}$. To view chloroplasts in individual cells, a piece of tissue was removed from the tube with fine forceps and placed on a microscope slide in a drop of water. A scalpel handle was used to tap and macerate the tissue fairly vigorously, and a Leica DM2700 M microscope with DIC/Nomarski optics was used to image and count chloroplast numbers with changing focus to avoid duplicate and uncounted chloroplasts (Fig. S3).

\section{The qualification of the anatomical limitations of mesophyll conductance}

The one-dimensional gas diffusion model of Tomas et al. [16] was applied in our present study to determine the anatomical limitations of mesophyll conductance, which was given as:

$$
g_{m}=\frac{1}{\frac{1}{g_{\text {ias }}}+\frac{\mathrm{RT}_{k}}{H \cdot g_{\text {liq }}}}
$$

where $g_{\text {ias }}$ and $g_{\text {liq }}$ are the gas phase conductance and liquid phase conductance, respectively. $\mathrm{R}$ is the gas constant (8.31 $\left.\mathrm{Pa} \mathrm{m}^{3} \mathrm{~K}^{-1} \mathrm{~mol}^{-1}\right), T_{\mathrm{k}}$ is the absolute temperature, and $H$ is Henry's law constant $\left(2943.3 \mathrm{~Pa} \mathrm{~m}^{3} \mathrm{~K}^{-1} \mathrm{~mol}^{-1}\right.$ for $\left.\mathrm{CO}_{2}\right)$. The $g_{\text {ias, }}$ was calculated as:

$$
g_{\text {ias }}=\frac{1}{r_{i a s}}=\frac{D_{a} \cdot f_{i a s}}{\Delta L_{i a s} \varsigma}
$$

where $r_{\text {ias }}$ is the resistance of the gas phase to $\mathrm{CO}_{2}, D_{\mathrm{a}}$ is the diffusion coefficient for $\mathrm{CO}_{2}$ in the gas phase and is set to $1.51 \times 10^{-5} \mathrm{~m}^{2} \mathrm{~s}^{-1}$ at $25^{\circ} \mathrm{C}, f_{\text {ias }}$ is the volume fraction of intercellular air space, $\Delta L_{\text {ias }}$ was taken as half of the mesophyll thickness, and $\varsigma$ is the diffusion path tortuosity $\left(1.57 \mathrm{~m} \mathrm{~m}^{-1}\right)$.

The $g_{\text {liq }}$ was determined by different components in the cell, including the conductance in the cell wall $\left(g_{\mathrm{cw}}\right)$, plasma membrane $\left(g_{\mathrm{pl}}\right)$, cytosol $\left(g_{\text {cyt }}\right)$, chloroplast envelope $\left(g_{\mathrm{en}}\right)$, and stroma $\left(g_{\mathrm{st}}\right)$. Eventually, $g_{\text {liq }}$ was calculated as:

$$
g_{\text {liq }}=\frac{S_{c}}{\left(r_{c w}+r_{p l}+r_{c y t}+r_{e n}+r_{s t}\right)}
$$

where $r_{\mathrm{cw}}, r_{\mathrm{pl}}, r_{\mathrm{cyt}}, r_{\mathrm{en}}, r_{\mathrm{st}}$ are the reciprocal terms of $g_{\mathrm{cw}}, g_{\mathrm{pl}}, g_{\text {cyt }}, g_{\mathrm{en}}$ and $g_{\text {st }}$, respectively. We used an estimate of $0.0035 \mathrm{~m} \mathrm{~s}^{-1}$ for the $g_{\mathrm{pl}}$ and $g_{\mathrm{en}}$ as Tomas et al. [16] suggested. In addition, $g_{\mathrm{cw}}, g_{\mathrm{cyt}}$, and $g_{\text {st }}$ were calculated as:

$$
g_{i}=\frac{1}{r_{i}}=\frac{r_{\mathrm{f}, \mathrm{i}} \cdot D_{\mathrm{w}} \cdot p_{\mathrm{i}}}{\Delta L_{\mathrm{i}}}
$$

where i stands for cell wall, cytosol, or stroma conductance. $r_{\mathrm{f}, \mathrm{i}}$ accounted for the reduction in the aqueous phase diffusion coefficient for $\mathrm{CO}_{2}\left(D_{\mathrm{w}}, 1.79 \times 10^{-9} \mathrm{~m}^{2}\right.$ $\mathrm{s}^{-1}$ at $25^{\circ} \mathrm{C}$ ) and was taken as 1.0 for cell walls and 0.3 for cytosol and stroma, respectively. $p_{\mathrm{i}}$ was the effective porosity $\left(\mathrm{m}^{3} \mathrm{~m}^{-3}\right)$ and was taken as 1.0 for the cytosol and stroma and 0.28 for the cell walls. $\Delta L_{\mathrm{i}}(\mathrm{m})$ is the diffusion path length in the corresponding component of the diffusion pathway.

The proportion of $g_{\mathrm{m}}$ determined by limited gas-phase conductance $\left(l_{\text {ias }}\right)$ was calculated as:

$$
l_{\text {ias }}=\frac{g_{\mathrm{m}}}{g_{\text {ias }}}
$$

The share of $g_{\mathrm{m}}$ by different components of the cellular phase conductance $\left(l_{\mathrm{i}}\right)$ was determined as:

$$
l_{\mathrm{i}}=\frac{g_{\mathrm{m}}}{g_{\mathrm{i}} S_{\mathrm{m}}}
$$

\section{Statistical analysis}

One-way ANOVA was applied to assess the differences in each parameter among the treatments with the SPSS 16.0 statistical software package. Significant differences $(P<0.05)$ among treatments are indicated by different letters using the least significant difference test. 


\section{Supplementary Information}

The online version contains supplementary material available at https:/doi. org/10.1186/s12870-020-02731-7.

Additional file 1: Figure S1. Representative light micrographs $(A \sim F$; scale bar $=200 \mu \mathrm{m})$ and transmission electron micrographs ( $G \sim L$; scale bar $=5 \mu \mathrm{m} ; M \sim R$, scale bar $=1 \mu \mathrm{m}$ ) of rice leaves supplied with $\mathrm{NH}_{4}{ }^{+}$ (AN) or $\mathrm{NO}_{3}{ }^{-}$(NN) under 3 different amounts, low N (0.71 mM, LAN and LNN), intermediate $N(2.86 \mathrm{mM}, \mathrm{MAN}$ and $\mathrm{MNN})$, and high $\mathrm{N}(7.14 \mathrm{mM}$, HAN and HNN). UEP, upper epidermis; LEP, lower epidermis; $V$, vascular bundle; CP, chloroplast; CW, cell wall; SG, starch grain; OG, osmiophilic globule. Figure S2. The relationship between mesophyll diffusion conductance $\left(g_{\mathrm{m}}\right)$ measured with the Harley et al. method and $g_{m}$ modeled with anatomical parameters (Eq. 13-16). Values are means \pm SD of four replicates. The data were fitted by linear regression. Broken lines correspond to the 1:1 relationship. Figure S3. Differential interference contrast image of chloroplasts in mesophyll cells separated from leaves. Leaves were cut into small pieces and fixed with 3.5\% glutaraldehyde, and the mesophyll cells were individually dispersed on the glass plate and observed by microscopy. The red circles in the figure indicate individual mesophyll cells, and the chloroplast numbers therein were counted; the arrows indicate that the mesophyll cells did not separate efficiently. Bars $=20 \mu \mathrm{m}$.

\section{Abbreviations}

$C_{\mathrm{C}}$ : Chloroplast $\mathrm{CO}_{2}$ concentration; $\mathrm{C}_{\mathrm{i}}$ : Intercellular $\mathrm{CO}_{2}$ concentration; $D_{L}$ : Leaf density; $g_{\mathrm{m}}$ : Mesophyll conductance; $g_{\mathrm{s}}$ : Stomatal conductance; HAN: High $\mathrm{NH}_{4}{ }^{+}$; $\mathrm{HNN}$ : High $\mathrm{NO}_{3}{ }^{-}$; LAN: Low $\mathrm{NH}_{4}{ }^{+} ; \mathrm{L}_{\mathrm{c}}$ : Chloroplast length; LNN: LoW $\mathrm{NO}_{3}{ }^{-} ; M_{\mathrm{A}}$ : Specific leaf weight; MAN: Intermediate $\mathrm{NH}_{4}{ }^{+}$; MNN: Intermediate $\mathrm{NO}_{3}{ }^{-} ; N_{c}$ : Chloroplasts number per mesophyll cell; $N_{L}$ : Leaf nitrogen content; $P_{n}$ : Net photosynthetic rate; PNUE: Photosynthetic nitrogen use efficiency; $S_{c}$ : Chloroplast surface area facing intercellular air spaces; $S_{e}$ : Chloroplasts section area; $S_{\text {mes: }}$ The surface area of mesophyll cells to the intercellular air-spaces; Sur: Chloroplast surface area; Vol: : Chloroplast volume; $T_{c}$ : Chloroplast thickness; $T_{L}$ : Leaf thickness; $T_{\mathrm{m}}$ : Mesophyll thickness; $T_{\text {mc }}$ : Mesophyll cell wall thickness

\section{Acknowledgements}

Not applicable.

\section{Authors' contributions}

S.W.G. and L.M.G. conceived and designed the experiments; L.M.G. and K.L.X. performed the experiments; L.M.G. and Z.F.L. analyzed the data and wrote the paper; L.M.G., Z.F.L. and L.D. helped in analysis of the results and manuscript writing; all authors discussed the results and wrote the manuscript. The author(s) read and approved the final manuscript.

\section{Funding}

This work was financially supported by the National Key Research and Development Program of China (2017YFD0200206) and the Special Fund for Agriculture Profession of China (20150312205). The funders have no role in the study design, data analysis and interpretation, and manuscript writing, but just provide the financial support.

\section{Availability of data and materials}

The datasets used and analyzed during the current study are available from the corresponding author on reasonable request.

\section{Ethics approval and consent to participate}

Not applicable.

\section{Consent for publication}

Not applicable.

\section{Competing interests}

The authors declare that they have no competing interests.
Received: 3 July 2020 Accepted: 5 November 2020

Published online: 18 November 2020

\section{References}

1. Poorter H, Evans JR. Photosynthetic nitrogen-use efficiency of species that differ inherently in specific leaf area. Oecologia. 1998;116:26-37.

2. Bernacchi CJ, Portis AR, Nakano H, von Caemmerer S, Long SP. Temperature response of mesophyll conductance. Implications for the determination of Rubisco enzyme kinetics and for limitations to photosynthesis in vivo. Plant Physiol. 2002;130:1992-8.

3. Zhu XG, De SE, Long SP. Optimizing the distribution of resources between enzymes of carbon metabolism can dramatically increase photosynthetic rate: a numerical simulation using an evolutionary algorithm. Plant Physiol. 2007;145:513-26.

4. Ripullone F, Grassi G, Lauteri M, Borghetti M. Photosynthesis-nitrogen relationships: interpretation of different patterns between Pseudotsuga menziesii and Populus $\times$ euroamericana in a mini-stand experiment. Tree Physiol. 2003;23:137.

5. Li Y, Ren BB, Ding L, Shen QR, Peng SB, Guo SW. Does chloroplast size influence photosynthetic nitrogen use efficiency? PLoS One. 2013;8:e62036.

6. Flexas J, Barbour MM, Brendel O, Cabrera HM, Carriqui M, Diaz-Espejo A, Douthe C, Dreyer E, Ferrio JP, Gago J, et al. Mesophyll diffusion conductance to $\mathrm{CO}_{2}$ : an unappreciated central player in photosynthesis. Plant Sci. 2012;193-194:70-84.

7. Lorimer GH. The carboxylation and oxygenation of Ribulose-1,5Bisphosphate: the primary events in photosynthesis and photorespiration. Annu Rev Plant Physiol. 2003;32:349-82.

8. Hassiotou F, Ludwig M, Renton M, Veneklaas EJ, Evans JR. Influence of leaf dry mass per area, $\mathrm{CO}_{2}$, and irradiance on mesophyll conductance in sclerophylls. J Exp Bot. 2009;60:2303-14.

9. Veromann-Jürgenson L-L, Tosens T, Laanisto L, Niinemets Ü. Extremely thick cell walls and low mesophyll conductance: welcome to the world of ancient living! J Exp Bot. 2017;68:1639-53.

10. Veromann-Jürgenson L-L, Brodribb TJ, Niinemets Ü, Tosens T. Pivotal role of mesophyll conductance in shaping photosynthetic performance across 67 structurally diverse gymnosperm species. Int J Plant Sci. 2020;181:116-28.

11. Hassiotou F, Renton M, Ludwig M, Evans JR, Veneklaas EJ. Photosynthesis at an extreme end of the leaf trait spectrum: how does it relate to high leaf dry mass per area and associated structural parameters? J Exp Bot. 2010;61: 3015-28.

12. Niinemets U, Wright IJ, Evans JR. Leaf mesophyll diffusion conductance in 35 Australian sclerophylls covering a broad range of foliage structural and physiological variation. J Exp Bot. 2009;60:2433-49.

13. Evans JR, Kaldenhoff R, Genty B, Terashima I. Resistances along the $\mathrm{CO}_{2}$ diffusion pathway inside leaves. J Exp Bot. 2009;60:2235-48.

14. Onoda Y, Wright IJ, Evans JR, Hikosaka K, Kitajima K, Niinemets Ü, Poorter H, Tosens T, Westoby M. Physiological and structural tradeoffs underlying the leaf economics spectrum. New Phytol. 2017;214:1447-63.

15. Terashima I, Hanba YT, Tazoe Y, Vyas P, Yano S. Irradiance and phenotype: comparative eco-development of sun and shade leaves in relation to photosynthetic $\mathrm{CO}_{2}$ diffusion. J Exp Bot. 2006;57:343-54.

16. Tomas M, Flexas J, Copolovici L, Galmes J, Hallik L, Medrano H, RibasCarbo M, Tosens T, Vislap V, Niinemets U. Importance of leaf anatomy in determining mesophyll diffusion conductance to $\mathrm{CO}_{2}$ across species: quantitative limitations and scaling up by models. J Exp Bot. 2013;64: 2269-81.

17. Carriquí M, Roig-Oliver M, Brodribb TJ, Coopman R, Gill W, Mark K, Niinemets Ü, Perera-Castro AV, Ribas-Carbó M, Sack L, et al. Anatomical constraints to nonstomatal diffusion conductance and photosynthesis in lycophytes and bryophytes. New Phytol. 2019;222:1256-70.

18. Bondada BR, Syvertsen JP. Leaf chlorophyll, net gas exchange and chloroplast ultrastructure in citrus leaves of different nitrogen status. Tree Physiol. 2003;23:553-9.

19. Bondada BR, Syvertsen JP. Concurrent changes in net $\mathrm{CO}_{2}$ assimilation and chloroplast ultrastructure in nitrogen deficient citrus leaves. Environ Exp Bot. 2005;54:41-8.

20. Poorter H, Niinemets U, Poorter L, Wright IJ, Villar R. Causes and consequences of variation in leaf mass per area (LMA): a meta-analysis. New Phytol. 2009;182:565-88.

21. Golvano M, Felipe M, Cintas A. Influence of nitrogen sources on chloroplast development in wheat seedlings. Physiol Plant. 1982;56:353-60. 
22. Raab TK, Terry N. Nitrogen source regulation of growth and photosynthesis in Beta vulgaris L. Plant Physiol. 1994;105:1159-66.

23. Antal T, Mattila H, Hakala-Yatkin M, Tyystjarvi T, Tyystjarvi E. Acclimation of photosynthesis to nitrogen deficiency in Phaseolus vulgaris. Planta. 2010;232: 887-98.

24. Harley PC, Loreto F, Dimarco G, Sharkey TD. Theoretical considerations when estimating the mesophyll conductance to $\mathrm{CO}_{2}$ flux by analysis of the response of photosynthesis to $\mathrm{CO}_{2}$. Plant Physiol. 1992;98:1429-36.

25. Sage RF, Pearcy RW. The nitrogen use efficiency of C3 and C4 plants. Plant Physiol. 1987;84:954-8.

26. Makino A, Nakano H, Mae T. Responses of Ribulose-1,5-bisphosphate carboxylase, cytochrome-F, and sucrose synthesis enzymes in rice leaves to leaf nitrogen and their relationships to photosynthesis. Plant Physiol. 1994; 105:173-9.

27. Ding L, Gao LM, Liu W, Wang M, Gu M, Ren BB, Xu GH, Shen QR, Guo SW. Aquaporin plays an important role in mediating chloroplastic $\mathrm{CO}_{2}$ concentration under high-N supply in rice (Oryza sativa $\mathrm{L}$ ) plants. Physiol Plant. 2015;156:215-26.

28. Lopes MS, Nogues S, Araus JL. Nitrogen source and water regime effects on barley photosynthesis and isotope signature. Funct Plant Biol. 2004;31:995-1003.

29. Yao BQ, Cao J, Zhao CM, Rengel Z. Influence of ammonium and nitrate supply on growth, nitrate reductase activity and N-use efficiency in a natural hybrid pine and its parents. J Plant Ecol. 2011;4:275-82.

30. Valentine AJ, Osborne BA, Mitchell DT. Form of inorganic nitrogen influences mycorrhizal colonisation and photosynthesis of cucumber. Sci Hortic. 2002;92:229-39.

31. Onoda Y, Hikosaka K, Hirose T. Allocation of nitrogen to cell walls decreases photosynthetic nitrogen-use efficiency. Funct Ecol. 2004;18:419-25.

32. Cheng LL, Fuchigami LH. Rubisco activation state decreases with increasing nitrogen content in apple leaves. J Exp Bot. 2000;51:1687-94.

33. Hanba YT, Miyazawa SI, Terashima I. The influence of leaf thickness on the $\mathrm{CO}_{2}$ transfer conductance and leaf stable carbon isotope ratio for some evergreen tree species in Japanese warm-temperate forests. Funct Ecol. 1999:13:632-9.

34. Lu ZF, Lu JW, Pan YH, Lu PP, Li XK, Cong RH, Ren T. Anatomical variation of mesophyll conductance under potassium deficiency has a vital role in determining leaf photosynthesis. Plant Cell Environ. 2016;39:2428-39.

35. Terashima I, Miyazawa S-I, Hanba YT. Why are sun leaves thicker than shade leaves? - consideration based on analyses of $\mathrm{CO}_{2}$ diffusion in the leaf. J Plant Res. 2001;114:93-105.

36. Muller O, Oguchi R, Hirose T, Werger MJ, Hikosaka K. The leaf anatomy of a broad-leaved evergreen allows an increase in leaf nitrogen content in winter. Physiol Plant. 2009;136:299-309.

37. Terashima I, Hanba YT, Tholen D, Niinemets Ü. Leaf functional anatomy in relation to photosynthesis. Plant Physiol. 2011;155:108-16.

38. Manter $D K$, Kerrigan $J . A / C_{i}$ curve analysis across a range of woody plant species: influence of regression analysis parameters and mesophyll conductance. J Exp Bot. 2004;55:2581-8.

39. Li Y, Ren BB, Yang XX, Xu GH, Shen QR, Guo SW. Chloroplast downsizing under nitrate nutrition restrained mesophyll conductance and photosynthesis in rice (Oryza sativa L.) under drought conditions. Plant Cell Physiol. 2012;53:892-900

40. Scafaro AP, Von Caemmerer S, Evans JR, Atwell BJ. Temperature response of mesophyll conductance in cultivated and wild Oryza species with contrasting mesophyll cell wall thickness. Plant Cell Environ. 2011;34:1999-2008.

41. Pyke K. Analysis of plastid number, size, and distribution in Arabidopsis plants by light and fluorescence microscopy. Methods Mol Biol. 2011; 774:19-32.

\section{Publisher's Note}

Springer Nature remains neutral with regard to jurisdictional claims in published maps and institutional affiliations.

Ready to submit your research? Choose BMC and benefit from:

- fast, convenient online submission

- thorough peer review by experienced researchers in your field

- rapid publication on acceptance

- support for research data, including large and complex data types

- gold Open Access which fosters wider collaboration and increased citations

- maximum visibility for your research: over $100 \mathrm{M}$ website views per year

At BMC, research is always in progress.

Learn more biomedcentral.com/submissions 